\title{
Eksistensi Budaya Lokal Dalam Usaha Pembangunan Karater Siswa Smp Kota Padang Sidimpuan
}

\author{
Armansyah Matondang, Yurial Arif Lubis; Agung Suharyanto \\ Fakultas Ilmu Sosial dan Ilmu Politik, Universitas Medan Area, Indonesia
}

Diterima September 2017; Disetujui November 2017; Dipublikasikan Januari 2018

\begin{abstract}
Abstrak
Globalisasi harus diakui telah membawa arus perubahan yang sangat besar. Tantangan kehidupan global sudah terasa dampaknya bagi kehidupan masyarakat Indonesia. Tidak jarang globalisasi juga melahirkan ekses negatif terhadap melemahnya kearifan budaya lokal. Globalisasi yang ditandai dengan kecanggihan di bidang teknologi komunikasi, informasi, dan transportasi membawa negara-negara di dunia masuk ke dalam sistem jaringan global, satu dunia telah mengubah menuju peradaban dunia baru. Di daerah sendiri, globalisasi di tuduh menjadi biang erong terdegradasinya budaya lokal. Tidak jarang saat ini berbagai usaha pemerintah untuk memajukan budaya lokal terus digerakkan. Penelitian ini menggunakan metode mixed methods. Sampel dalam penelitian ini berjumlah 653 guru dengan kata lain sampel yang digunakan dalam penelitian ini adalah sebanyak 65,3 responden yang dibulatkan menjadi 63 orang. Hasil penelitian ini menunjukkan bahwa sekolah di tingkatan SMP Kota Padang Sidimpuan belum secara maksimal menerapkan budaya lokal dalam kurikulum yang mereka terapkan. Sekolah tidak menempatkan budaya lokal dalam posisi strategis dalam sistem pembelajaran. Selain itu pemerintah daerah juga tidak memiliki inisiatif untuk ikut serta mengembangkan budaya lokal.
\end{abstract}

Kata Kunci: Budaya, Sisiwa, Sekolah

\begin{abstract}
Globalization must be acknowledged to have brought a tremendous flow of change. The challenges of global life have felt its impact on the life of Indonesian society. Not infrequently globalization also gave birth to negative excesses on the weakening of local cultural wisdom. Globalization is characterized by sophistication in the field of communications, information and transport technology bringing the world's countries into a global network system, one world has transformed into a new world civilization. In the region itself, globalization is alleged to be the source of the eradication of local culture. Not infrequently now various government efforts to promote local culture continues to be driven. This research uses mixed methods method. The sample in this study amounted to 653 teachers in other words the sample used in this study was as many as 65.3 respondents rounded to 63 people. The results of this study indicate that schools in junior high school Padang Sidimpuan not maximally apply the local culture in the curriculum that they apply. Schools do not put local culture in a strategic position in the learning system. In addition, local governments also do not have the initiative to participate in developing local culture.
\end{abstract}

Keywords: Culture, Sisiwa, School

How to Cite: Matondang, A., Yurial A.L., Agung S., (2018), Eksistensi Budaya Lokal Dalam Usaha Pembangunan Karater Siswa Smp Kota Padang Sidimpuan, Anthropos: Jurnal Antropologi Sosial dan Budaya, 3 (2): 103-116

*Corresponding author:

E-mail: armansyah@staff.uma.ac.id p-ISSN 2460-4585 e-ISSN 2460-4593 


\section{PENDAHULUAN}

Selama ini pengelolaan sumber daya manusia khususnya siswa untuk mensejahterakan masyarakat belum maksimal. Pengelolaan dalam pembangunan kesiswaan tidak hanya mengacu pada pemerintah, namun juga membutuhkan peran serta para cendikiawan, pelaku bisnis dan masyarakat umum. Selama ini, kelemahan mendasar dalam pembangunan kesiswaan adalah integritas dan kreatifitas. Dalam pembangunan siswa yang berlandaskan potensi dan kreativitas pengembangan ide kreatif dapat dilakukan dengan pembentukan budaya kreatif. Pembentukan budaya kreatif adalah pembentukan citra budaya baru tanpa harus menanggalkan identitas budaya lama. Dibutuhkan kolaborasi setiap elemen masyarakat untuk dapat membentuk citra budaya baru. Pemerintah, akademisi atau cendikiawan dan pelaku bisnis aktor utama dalam pembentukan budaya kreatif. Pemerintah, akademisi atau cendikiawan harus dapat berelaborasi sehingga dapat memperkaya pengetahuan antar elemen tersebut yang pada akhirnya menghasilkan sinergi berupa ide-ide atau cara pandang baru. inergi ketiga elemen masyarakat tersebut akan membentuk budaya kreatif tanpa menghilangkan identitas budaya lama.

Pengembangan citra budaya baru tidak serta merta menghilangkan belief masyarakat yang sudah terbentuk sebelumnya sehingga konflik dapat dihindari. Pengembangan citra budaya baru harus didukung dengan integritas yang tinggi antar elemen utama pembentukan budaya kreatif di masyarakat. Integritas atau kejujuran akan menumbuhkan rasa toleransi dengan tetap berlandaskan khasanah keagamaan dan budaya lokal dan meningkatkan penghargaan atas kreasi seseorang. Toleransi dan apresiasi atas hak cipta adalah kunci pengembangan budaya kreatif. Toleransi atas sebuah perbedaan akan menumbuhkan ide-ide kreatif di masyarakat. Penghargaan atas hak cipta akan mendorong setiap orang untuk berusaha mewujudkan ide kreatif menjadi sebuah barang dan jasa yang mempunyai nilai ekonomi tinggi.
Budaya mempunyai peran ganda dalam pembangunan siswa yang berlandaskan potensi dan kreativitas. Selain sebagai akselerator atau faktor utama penggerak dalam pengembangan potensi dan kreativitas siswa, budaya adalah resource atau sumber daya yang dapat dikembangkan menjadi sebuah dasar pengembangan pembangunan bernilai tinggi.

Sebagai jiwa yang mempunyai daya ekplorasi tinggi siswa adalah sumber daya insani yang dapat dibentuk menjadi insan-insan kreatif dan mempunyai integritas tinggi dalam mewujudkan sebuah ide. Dengan mendorong tingkat kreatifitas siswa berarti mengarahkan siswa untuk lebih produktif. Pembentukan insan-insan muda menjadi insan kreatif akan meningkatkan produktifitas siswa sehingga dapat mengurangi tingkat pengangguran di Indonesia yang sekarang ini mencapai 9.342 juta jiwa. Dengan pembangunan yang berlandaskan kreatifitas masyarakat dan siswa sebagai aktor utama, sumber daya yang ada dapat dimanfaatkan secara efisien. Pemanfaatan kreatifitas siswa akan mendorong pembentukan lapangan kerja baru yang pada akhirnya akan mengurangi jumlah pengangguran di Indonesia.

Kemudian di sisi lain kebijakan Pendidikan Budi Pekerti/pendidikan karakter dalam Kurikulum Sekolah mengalami pasang surut. Berdasarkan hasil analisis Supriadi (2004: 162-166) terhadap kurikulum Pendidikan Budi Pekerti/pendidikan karakter, maka dapat disimpulkan bahwa pendidikan budi pekerti/pendidikan karakter pertama kali diperkenalkan dalam Kurikulum 1947 sebagai mata pelajaran tersendiri; pada Kurikulum 1964 disatukan menjadi pelajaran agama/budi pekerti; pada Kurikulum 1968 pendidikan budi pekerti hilang, baik sebagai nama mata pelajaran tersendiri maupun sebagai mata pelajaran yang diintegrasikan dengan mata pelajaran lain. Kemudian pada Kurikulum 1975 pendidikan budi pekerti sudah tidak muncul lagi, yang muncul adalah mata pelajaran Pendidikan Moral Pancasila (PMP) dan mata pelajaran Pendidikan Agama menjadi mata pelajaran yang berdiri sendiri. Pada Kurikulum 1984 menurut Chan dan Sam (2005: 
18) "Pendidikan budi pekerti dihapuskan dalam daftar mata pelajaran di sekolah". Pada kurikulum 1994 pendidikan budi pekerti/pendidikan karakter kurang mendapat perhatian. Demikian juga pada Kurikulum Tingkat Satuan Pendidikan (KTSP) tahun 2006 tidak disebutkan pendidikan budi pekerti sebagai mata pelajaran tersendiri. Kebijakan pemerintah seperti ini berdampak kurang berjalannya pendidikan budi pekerti di sekolah.

Globalisasi harus diakui telah membawa arus perubahan yang sangat besar. Tantangan kehidupan global sudah terasa dampaknya bagi kehidupan masyarakat Indonesia. Tidak jarang globalisasi juga melahirkan ekses negatif terhadap melemahnya kearifan budaya lokal. Globalisasi yang ditandai dengan kecanggihan di bidang teknologi komunikasi, informasi, dan transportasi membawa negara-negara di dunia masuk ke dalam sistem jaringan global, satu dunia telah mengubah menuju peradaban dunia baru. Globalisasi dalam kehidupan politik, ekonomi, sosial, dan budaya dapat memberikan dampak positif maupun negatif bagi bangsa Indonesia sebab dengan kecanggihan teknologi itu seluruh informasi yang datang dari berbagai belahan dunia dapat diakses langsung di mana saja dan kapan saja. Apabila tidak diantisipasi dengan memperkuat filter budaya dan agama, maka globalisasi akan dapat merugikan terhadap eksistensi nilai-nilai budaya bangsa.

Masyarakat Indonesia merupakan masyarakat yang majemuk baik dari segi budaya, agama, maupun bahasa yang memiliki nilai-nilai luhur sebagai local wisdomnya. Menurut Alwasilah (2009: 50) "Ada sejumlah praktik pendidikan tradisional (etnodidaktik) yang terbukti ampuh, seperti pada masyarakat adat Kampung Naga dan Baduy dalam melestarikan lingkungan". Namun, sebenarnya secara keseluruhan masyarakat adat yang ada telah menyelenggarakan pendidikan yang dapat disebut sebagai pendidikan tradisi, termasuk pendidikan budi pekerti secara baik. Masyarakat adat yang masih tetap eksis, telah memelihara local wisdom-nya menjadi bagian yang tidak terpisahkan dari kehidupan sehari-hari dan menjadi dasar bagi solusi terhadap permasalahan yang terjadi di masyarakatnya.

Fenomena yang terjadi sekarang perubahan sosial berimplikasi pada semakin mudahnya siswa mengakses berbagai informasi dengan mudah. Tidak jarang berbagai informasi terkait tentang hal-hal negatif. Di kalangan siswa dan generasi muda juga terjadi perilaku menyimpang yang tidak mencerminkan budi pekerti luhur seperti geng motor, perkelahian pelajar (tawuran), perkelahian antar mahasiswa, tawuran di antara geng pelajar perempuan, free sex, dan aborsi. Demikian juga mulai tampak adanya tanda-tanda meninggalkan budaya lokal dan beralih ke budaya barat. Hal tersebut seperti dalam bidang seni, fashion, kegemaran, selera makanan, dunia hiburan, bahasa, gaya hidup, interaksi anak dengan orang tua, interaksi murid dengan guru, budaya sekularisme, pragmatisme, dan hedonisme. Menurut data Polres Padangsidimpuan sendiri, hingga saat ini siswa Sekolah Menengah Pertama (SMP) di Kota Padang Sidimpuan ikut menambah daftar panjang pengguna narkoba di wilayahnya. Keberadaan media sosial semakin mempermudah akses jual beli dan mempermudah akses penjualan. Selain itu, konten media online juga mendorong berbagai aktivitas negatif bagi siswa.

Siswa harus disiapkan sejak dini untuk berpartisipasi dalam pembangunan. Pembentukan kreatifitas siswa dapat dimulai dari lingkungan pendidikan seperti sekolah. Melalui arahan akademisi sejak dini siswa diperkenalkan pada dunia usaha atau profesional dan diajak untuk belajar memahami lingkungan dan budaya bangsa. Dengan demikian siswa dapat terpacu untuk berkarya dan dapat meningkatkan rasa nasionalisme siswa. Dimana pada akhirnya siswa dapat memberikan sumbangan nyata bagi kemajuan bangsa dan negara.oleh karena itu dalam penelitian ini, peneliti akan mencoba melihat eksistensi budaya lokal dalam usaha pembangunan karater siswa SMP Kota Padang Sidimpuan. 
Banyak ahli telah mencoba merumuskan definisi dari kata "belajar". Hamalik (2010: 36-37) menyebutkan dua pendapat tentang belajar yang hampir sama. Salah satu pendapat menyebutkan bahwa belajar adalah modifikasi atau memperteguh kelakuan melalui pengalaman. Sedangkan pendapat lain mengatakan bahwa belajar adalah suatu proses perubahan tingkah laku individu melalui interaksi dengan lingkungan. Hal ini berarti bahwa perubahan tingkah laku merupakan bukti atau indikator dari belajar.

Definisi lain dari Semiawan (2008: 6) yang menyebutkan bahwa belajar merupakan perubahan perilaku sifat dan kemampuan yang relatif permanen, yang datang dari dalam dirinya, dan dapat ditinjau terutama dari pengaruh lingkungan atau dari faktor genetis yang berbeda antara satu dengan lainnya. Berdasarkan definisi tersebut, hasil dari belajar adalah perubahan tingkah laku yang relatif tetap dalam diri individu.

Belajar memiliki karakteristik tertentu (Hamalik, 2010: 49-50) yaitu berbeda dengan kematangan, adanya perubahan fisik dan mental, serta hasilnya relatif menetap. Pengertian ini senada dengan definisi dari Conny R. Semiawan yang menekankan pada perubahan dan hasil belajar yang relatif menetap pada individu tersebut. Ada pula unsur-unsur dinamis yang terdapat dalam proses belajar (Hamalik, 2010: 50-52) meliputi motivasi, bahan belajar, alat bantu belajar, suasana belajar, dan kondisi subjek belajar. Unsur-unsur tersebut saling berkaitan dan berpengaruh satu dengan yang lainnya.

Berdasarkan beberapa pendapat di atas, peneliti dapat menyimpulkan bahwa belajar merupakan proses perubahan perilaku, sifat, dan kemampuan baik fisik maupun mental yang disebabkan adanya interaksi dengan lingkungan di sekitarnya dan hasilnya bersifat relatif menetap pada diri individu.

Selain pengertian dari kata "belajar", ada pula istilah "pembelajaran". UU No 20 Tahun 2003 pasal 1 ayat 19 menyebutkan bahwa "Pembelajaran adalah proses interaksi peserta didik dengan pendidik dan sumber belajar pada suatu lingkungan belajar". Pembelajaran adalah suatu kombinasi yang tersusun meliputi unsurunsur manusiawi, material, fasilitas, perlengkapan, dan prosedur yang saling mempengaruhi mencapai tujuan pembelajaran (Hamalik, 2010: 57). Pendapat ini lebih menyoroti pada unsur-unsur dalam sebuah pembelajaran. Hilangnya salah satu atau beberapa unsur- unsur tersebut akan sangat berpengaruh terhadap keberhasilan suatu pembelajaran. Unsur manusiawi yang dimaksud adalah siswa, guru, dan tenaga lain yang terlibat dalam sistem pengajaran. Unsur material yang ada dalam pembelajaran meliputi buku, papan tulis, kapur, film, slide, dan lain-lain. Fasilitas dan perlengkapan terdiri dari ruang kelas, perlengkapan audio visual, komputer, dan lain-lain. Prosedur yang dimaksud meliputi jadwal, metode, penyampaian informasi, praktik, belajar, ujian, dan sebagainya.

Pembelajaran adalah kegiatan guru secara terprogram dalam desain instruksional, untuk membuat siswa belajar secara aktif, yang menekankan pada penyediaan sumber belajar (Dimyati dan Mudjiono, 2006: 297). Pendapat ini menekankan bahwa pembelajaran merupakan sebuah proses antara guru dengan siswa untuk membuat sebuah kebermaknaan dalam belajar melalui sumber belajar.

Hamalik (2010: 65-70) menjelaskan ciriciri dan unsur-unsur yang ada dalam proses pembelajaran. Suatu sistem pembelajaran memiliki tiga ciri utama yaitu memiliki rencana khusus, kesaling tergantungan antara unsurunsurnya, dan tujuan yang hendak dicapai. Sedangkan unsur minimal dalam sistem pembelajaran adalah siswa, tujuan, dan prosedur. Unsur dinamis pembelajaran pada diri guru meliputi motivasi dan kondisi guru. Unsur pembelajaran kongruen dengan unsur belajar meliputi motivasi belajar, sumber bahan belajar, alat bantu belajar, suasana belajar, subjek yang belajar.

Berdasarkan beberapa pendapat di atas, peneliti dapat menyimpulkan bahwa pembelajaran merupakan sebuah proses yang merupakan kombinasi dari unsur-unsur manusiawi, material, fasilitas, perlengkapan, dan prosedur untuk mencapai tujuan 
pembelajaran yaitu kebermaknaan dalam belajar. Unsur-unsur yang harus ada dalam pembelajaran meliputi siswa, guru, sumber, alat, media, perencanaan, pelaksanaan, serta penilaian. Hal-hal inilah yang akan dikaji lebih lanjut dalam penelitian ini.

Belajar dan mengajar adalah dua buah peristiwa yang berbeda tetapi terdapat keterkaitan yang saling berpengaruh dan saling menunjang satu sama lain. Berdasarkan teori belajar, ada lima pengertian mengajar yang dijelaskan oleh Hamalik (2010: 58-65) meliputi:

a) Mengajar adalah upaya menyampaikan pengetahuan kepada peserta didik/siswa di sekolah; b) Mengajar adalah mewariskan kebudayaan kepada generasi muda melalui lembaga pendidikan sekolah; c) Pembelajaran adalah upaya mengorganisasi lingkungan untuk menciptakan kondisi belajar bagi peserta didik; d) Pembelajaran adalah upaya mempersiapkan peserta didik untuk menjadi warga masyarakat yang baik; e) Pembelajaran adalah suatu proses membantu siswa menghadapi kehidupan masyarakat sehari-hari.

Nasution (2010: 5) menjelaskan bahwa mengajar dikatakan berhasil apabila anak-anak belajar sebagai akibat usaha itu. Bagi guru, belajar adalah mengubah kelakuan anak, jadi lebih cenderung kepada pembentukan pribadi anak. Lebih lanjut, Nasution (2010: 5-7) juga menyimpulkan definisi mengajar menjadi tiga hal, yaitu mengajar berarti membimbing aktivitas anak, mengajar berarti membimbing pengalaman anak, dan mengajar berarti membantu anak berkembang dan menyesuaikan diri kepada lingkungan.

\section{METODE PENELITIAN}

Metode yang digunakan dalam penelitian ini adalah metode mixed methods. Penelitian ini merupakan suatu langkah penelitian dengan menggabungkan dua bentuk penelitian yang telah ada sebelumnya yaitu penelitian kualitatif dan penelitian kuantitatif. Menurut Creswell (2010:5), penelitian campuran merupakan pendekatan penelitian yang mengkombinasikan antara penelitian kualitatif dengan penelitian kuantitatif. Menurut pendapat Sugiyono (2011:
404) menyatakan bahwa metode penelitian kombinasi (mixed methods) adalah suatu metode penelitian yang mengkombinasikan atau menggabungkan antara metode kuantitatif dengan metode kualitatif untuk digunakan secara bersama-sama dalam suatu kegiatan penelitian, sehingga diperoleh data yang lebih komprehensif, valid, reliable dan obyektif.

Populasi dalam penelitian ini adalah 653 guru Sekolah Menengah Pertama (SMP) di Kota Padang Sidimpuan. Sampel adalah wakil dari populasi yang dianggap representative atau memenuhi syarat untuk menggambarkan keseluruhan dari populasi yang diwakilinya. Jika populasi lebih dari 100 maka dianjurkan sampel yang diambil antara $10-15 \%$ atau 2025\% (Arikunto, 2002:107). Dikarenakan jumlah populasinya dari jumlah anggota 653 orang dan lebih dari 100 maka sampelnya dimbil dari 10\% dari jumlah populasi, yaitu 65,3 maka dibulatkan menjadi 65 guru. Teknik penarikan sampel dalam penelitian ini menggunakan random sampling atau teknik penarikan acak.

Penelitian ini dilaksanakan di seluruh Sekolah Menengah Pertama (SMP) di Kota Padang Sidimpuan. Teknik pengumpulan data yang dilakukan dalam penelitian ini, adalah pertama Studi literatur dan dokumentasi dari berbagai jurnal, buku, hasil penelitian dan media lainnya yang berhubungan dengan topik penelitian, selain itu dilakukan juga studi dokumentasi untuk memperoleh data sekunder. Kedua, Kuesioner penelitian digunakan untuk mengumpulkan data kuantitatif, kuesioner disebarkan kepada seluruh guru SMP yang menjadi sampel dalam penelitian ini. Ketiga Wawancara mendalam terhadap informan penelitian yang dipilih melalui purposive sampling. Wawancara dalam penelitian ini dilakukan dengan semi terstruktur dan mendalam. Keempat Obeservasi lapangan, pengamatan yang didasarkan pada topik penelitian dan realita lapangan yang ditemukan.

Proses kegiatan analisis data dalam penelitian ini dimulai dari pengumpulan data dari sumber data berupa individual in-depth interview, group interview dengan teknik Diagram Venn, observasi dan serta dokumentasi. Data-data yang telah terkumpul 
tersebut dibaca untuk mempelajari, dipilahpilah baik data verbal maupun non verbal untuk diklasifikasikan berdasarkan kategori data, Gambar 1. Proses Analisa Data sehingga menemukan pola yang sesuai dengan penelitian ini. Untuk jelasnya dapat dilihar dari gambar.1. berikut:

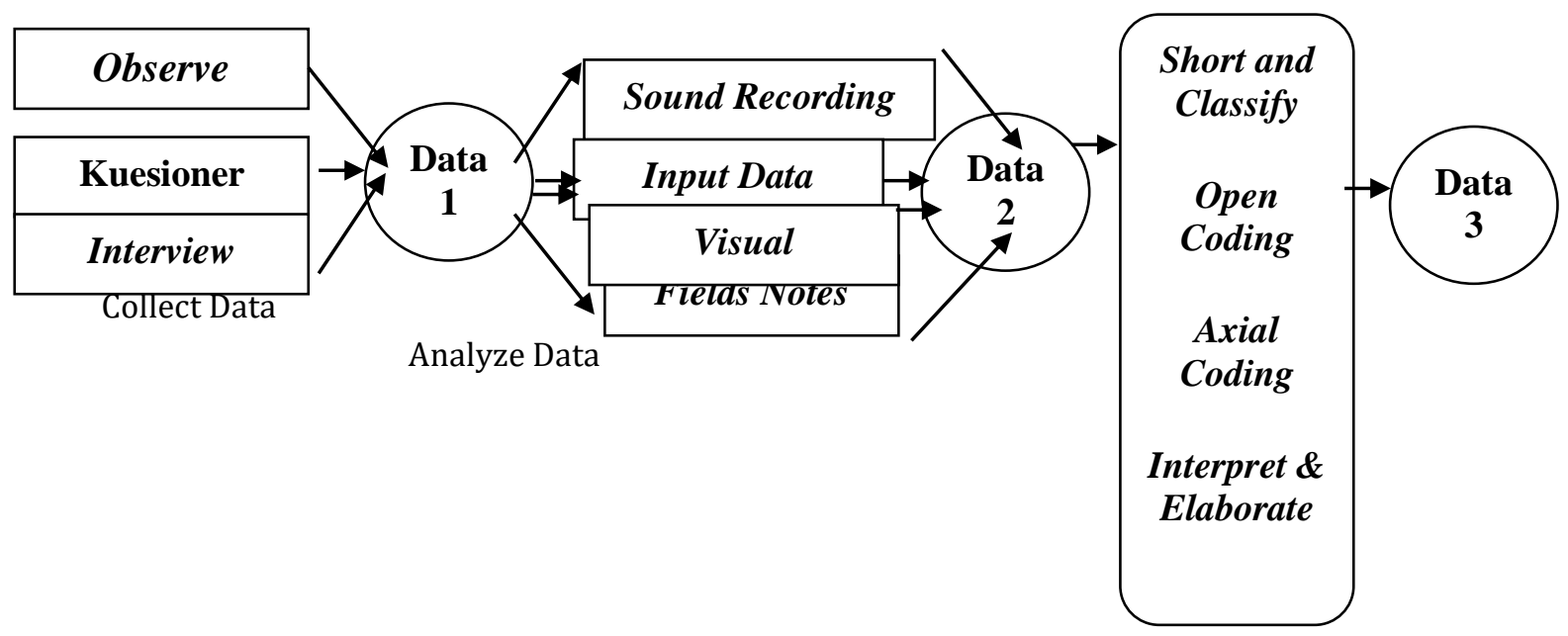

Sumber: Ellen (dalam Neuman, 2006, h.468)

\section{HASIL DAN PEMBAHASAN}

Berbicara mengenai Pembelajaran Berbasis Budaya, terdapat unsur pokok dalam pembelajaran yaitu "budaya". Sering pula kita mendengar kata "kebudayaan". Banyak ahli sosial budaya yang mendefinisikan kata "budaya" dan "kebudayaan". Sama atau bedakah kedua istilah tersebut, berikut ini penjelasannya.

Hasibuan (2002: 119) menyebutkan bahwa jika dilihat dari asal bahasa definisi kebudayaan, yakni bahasa Sansekerta, perkataan "kebudayaan" telah ada dalam khasanah kosa kata Indonesia jauh sebelum istilah tersebut dipakai di dunia barat. Sansekerta adalah bahasa dalam agama Hindu yang telah ada di bumi Indonesia ini lebih dari 10 abad lamanya.

Pendapat lain dalam Widagdho (2010: 18) yang mengatakan bahwa "budaya" adalah sebagai suatu perkembangan dari kata majemuk budi-daya, yang berarti daya dari budi, karena itu mereka membedakan antara budaya dengan kebudayaan. Budaya lebih merujuk pada daya dari budi yang berupa cipta, rasa, dan karsa, sedangkan kebudayaan lebih kepada hasil dari cipta, rasa, dan karsa tersebut.

Koentjaraningrat (Pelly, 1994: 22) mendefinisikan kata "kebudayaan" berasal dari bahasa Sansekerta "buddhayah", yaitu bentuk jamak "buddhi" yang berarti "budi" atau "akal". Dengan demikian kebudayaan dapat diartikan "hal-hal yang bersangkutan dengan akal". Koentjaraningrat (Widagdho, 2010: 19-20) juga mengatakan kebudayaan adalah keseluruhan manusia dari kelakuan dan hasil kelakuan yang teratur oleh tata kelakuan yang harus didapatnya dengan belajar dan tidak semuanya tersusun dalam kehidupan masyarakat.

Budaya atau kebudayaan adalah seluruh hasil usaha manusia dengan budhinya berupa segenap sumber jiwa, yakni cipta, rasa, dan karsa (Widagdho, 2010: 27). Pendapat ini menekankan bahwa budaya merupakan hasil dari cipta, rasa, dan karsa manusia.

Henslin (2006: 38) menyebutkan kebudayaan (culture) meliputi bahasa, kepercayaan, nilai, norma, perilaku, dan bahkan objek material yang diwariskan dari suatu generasi ke generasi berikutnya. Semua unsur tersebut merupakan indikasi dari kebudayaan. Berdasarkan beberapa definisi di atas dapat peneliti dapat menyimpulkan bahwa budaya adalah apa yang ada dalam pikiran/akal budi manusia, sedangkan kebudayaan adalah hasil berpikir akal budi manusia yakni cipta, rasa, dan karsa yang teratur dan tersusun dalam kehidupan masyarakat. 
Dalam penelitian ini, peneliti mengamati kebudayaan yang ada pada tingkat pengetahuan pendidik tentang budaya lokal, kurikulum budaya lokal dan mata pelajaran budaya lokal dalam penyelenggaraan pendidikan di Kota Padang Sidempuan. Unsur-unsur tersebut juga berkaitan dengan wujud budaya yang akan diteliti oleh peneliti.

Koentjaraningrat (Pelly, 1994: 25) menggolongkan tiga wujud kebudayaan, yaitu: 1) Wujud kebudayaan sebagai suatu kompleks dari ide-ide, gagasan, nilai-nilai, norma-norma, peraturan dan sebagainya. 2) Wujud kebudayaan sebagai suatu kompleks aktivitas serta tindakan berpola dari manusia dalam masyarakat. 3) Wujud kebudayaan sebagai benda-benda hasil karya manusia.

Unsur-unsur kebudayaan menurut Koentjaraningrat (2000: 2) adalah sebagai berikut: 1. Sistem religi dan upacara keagamaan, 2. Sistem dan organisasi kemasyarakatan, 3. Sistem pengetahuan, 4. Bahasa, 5. Kesenian, 6. Sistem mata pencaharian hidup, 7. Sistem teknologi dan peralatan

Sutarno (2007: 1.11) menyebutkan halhal yang termasuk budaya dan non-budaya yaitu, Hal-hal yang non budaya mencakup benda yang keberadaannya sudah ada dengan sendirinya atau ciptaan Tuhan yang tidak/belum mendapat sentuhan aktivitas manusia (benda-benda alamiah seperti batu, pohon, gunung, tanah, planet), sedangkan budaya mencakup sesuatu yang keberadaannya sudah mendapat sentuhan tangan manusia (misal, patung marmer/onix, bonsai, bangunan, aturan makan dan lain-lain).

Penelitian ini mengkaji pembelajaran dengan memfokuskan wujud budaya menurut pendapat Koenjtaraningrat. Wujud budaya pada tingkat pengetahuan pendidik tentang budaya lokal, kurikulum budaya lokal dan mata pelajaran budaya lokal dalam penyelenggaraan pendidikan di Kota Padang Sidempuan yang menjadi fokus penelitian ini, wujud budaya baik secara ide, perilaku, maupun benda- benda hasil karya manusia.

Wujud budaya secara ide seperti nilainilai dan norma dalam kurikulum budaya lokal di sekolah. Wujud budaya secara perilaku atau aktivitas adalah bagaimana pada tingkat pengetahuan pendidik tentang budaya lokal. Wujud budaya secara fisik atau hasil karya adalah mata pelajaran budaya lokal.

Menurut Brennan (2009) bahwa konsep budaya lokal memiliki banyak definisi dan sudut pandang. Sisi sosial, biasa diartikan secara luas meliputi seluruh cara hidup termasuk hukum, nilai dan perilaku yang diinginkan. Pada dasarnya, budaya dapat dilihat sebagai pemikiran yang universal. Pemikiran ini terpola dari waktu ke-waktu sehingga menjadi sebuah kebiasaan pada masyarakat tertentu. Lebih lanjut, Brennan juga mengatakan bahwa budaya lokal menjadi identitas bagi suatu masyarakat. Identitas ini meliputi pemahaman umum, kebiasaan, dan nilai-nilai.

$$
\text { Adapun Judistira (2008: }
$$

mengatakan bahwa kebudayaan lokal bukan hanya terungkap dari bentuk dan pernyataan rasa keindahan melalui kesenian belaka; tetapi termasuk segala bentuk, dan cara-cara berperilaku, bertindak, serta pola pikiran yang berada jauh dibelakang apa yang tampak tersebut. Sedangkan seorang antropolog, Sir Edward dari Inggris mendefenisikan budaya lokal sebagai "the complex whole of ideas and things produced by men in their historical experience" (keseluruhan ide dan barang yang dihasilkan oleh manusia dalam pengalaman sejarahnya masyarakat tertentu)

Dari definisi di atas, maka budaya lokal dalam penelitian ini adalah kumpulan dari keseluruhan ide (abstrak) dan barang (artefak) dari hasil pengalaman satu masyarakat Kota Padang Sidempuan yang menjadi identitas dari masyarakat itu sendiri.

Dalam penelitian ini, angket disebarkan kepada responden dan kemudian mewawancarainya secara mendalam pada masing-masing guru yang mengajar dari berbagai usia, agama, etnisitas dan Janis kelamin yang berbeda. Maka, dapat didapatkan beberapa hasil sesuai dengan pendistribusiannya.

Distrubusi Responden berdasarkan Usia, sebanyak 70,72\% responden berusia 21-40 tahun dan 19 responden atau 29,29\% sisanya berusia 40-60 tahun. Distribusi Responden 
Berdasarkan Suku, bahwa responden dalam penelitian ini didominasi oleh guru dengan suku bangsa Mandailing, lalu responden dengan suku bangsa Batak sebanyak 17 atau 26,18\%, responden dengan suku bangsa Nias sebanyak 9 responden atau 13,62\%. Responden dengan suku bangsa Jawa sebanyak4 responden atau 6,15\%, Berdasarkan pendidikannya, dapat dilihat bahwa dari total 65 responden dalam penelitian ini, $100 \%$ responden merupakan tamatan strata 1.

Kota Padang Sidimpuan merupakan kota yang didominasi oleh suku Mandailing di dalamnya. Menurut data Badan Pusat Statistik tahun 2016 jumlah suku Mandailing di daerah Padangsidimpuan menjapai $75 \%$ dari total keseluruhan penduduk. Oleh karena itu ritusritus budaya sangat mendominasi sistem kehidupan masyarakat, mulai dari kehidupan politik, sosial dan budaya. Dari data di atas dapat dilihat bagaimana persepsi masyarakat dalam melihat pentingnya budaya lokal dalam kehidupan sehari-hari, sebanyak 50 atau $76,91 \%$ responden menjawab sangat setuju bahwa budaya lokal merupakan hal yang penting dalam kehidupan dan 15 atau 23,09\% sisanya menjawab setuju. Sangat sulit memang memisahkan budaya dengan kehidupan seharihari masyarakat kota Padangsidimpuan. Hal ini senada dengan yang diungkapkan oleh Ibu Anggreani Nasution:

“...budaya di Pasid (Padang Sidimpuan) sudah mendarah daging dalam kehidupan kami kususnya budaya Mandailing. Bisa kita tengok di berbagai acara pernikahan, khitan, masuk rumah baru di situ budaya sangat kental. Belum lagi martutur (sistem kekerabatan) yang gak bisa lepas. Kalau ini hilang bisa kacau balau kekeluargaan kami. Ini lah yang diturunkan sama orang tuakita makanya sampai saat ini budaya masih sangat penting..."

Pranata budaya sangat melekat dalam sistem sosial masyarakat. Hal ini kemudian membuat budaya menjadi elemen yang tidak terpisahkan dalam kehidupan sosial masyarakat Kota Padang Sidimpuan.

Keberlangsungan Budaya Lokal Pada Kehidupan Masyarakat Kedepan, sebanyak 48 responden atau $73,82 \%$ dari total responden menyatakan sangat setuju jika budaya lokal harus dipertahan di Kota Padangsidimpuan. Sementara itu sebanyak 17 responden atau sebesar 26,28\% dari total responden menyatakan setuju untuk mempertahankan budaya lokal di Kota Padangsidimpuan. Budaya yang telah medarah daging dalam kehidupan masyarakat Kota Padang Sidimpuan membuat masyarakat sangat tergantung dengan kebudayaan itu sendiri. Ritus-ritus yang terdapat dalam budaya menjadi roll untuk setiap tindakan yang individu lakukan dalam masyarakat.

Budaya Lokal Dibutuhkan Masyarakat, dari responden sebanyak 39 orang atau sebesar $60 \%$ responden menyatakan sangat setuju terkait kebutuhan masyarakat lokal terhadap budaya lokal. Sisa responden sebanyak 26 orang atau sebesar $40 \%$ menyatakan setuju terkait kebutuhan masyarakat lokal terhadap kebudayaan lokal. Perkembangan teknologi ternyata tidak serta merta mambawa dampak yang signifikan terhadap perubahan sosial budaya masyarakat Kota Padang Sidimpuan. Budaya masih menjadi penting.

Budaya Lokal Tergerus Globalisasi, ddari responden sebanyak 22 atau sebesar 33,3\% dari total responden menganggap sangat setuju terkait pernyataan budaya lokal Kota Padangsidimpuan yang mulai tergerus globalisasi. Sementara itu sebanyak 39 atau $60,3 \%$ dari total responden menyatakan setuju terkait pertnyataan tersebut. Sebanyak 2 responden atau sebesar 3,07\% menanggapi biasa saja dengan pernyataan tergerusnya budaya lokal. Hanya 2 responden atau sebesar $3,07 \%$ dari total responden yang menyatakan tidak setuju jika saat ini budaya lokal Kota Padangsidimpuan mulai tergerus globalisasi.

Responden juga menyadari bahwa budaya mereka saat ini mengalami kemunduran akibat adanya arus globalisasi. Masyarakat menganggap budaya menjadi sebuah sistem hidup yang kuno dan apabila tetap dilakukan akan dianggap individu atau masyarakat yang ketinggalan jaman. Hal ini diungkapkan oleh Ibu Harahap:

“...sekarang bisa kita tengok lah, berapa orang muda yang paham adat. Kurasa kalau 
kami yang tua ini udah gak ada, tradisi itu lenyap sudah. Tidak ada lagi yang meneruskan. Anak sekarang bagus belajar maen game daripada belajar adat..."

Regenerasi ternyata menjadi salah satu unsur yang dinilai oleh responden sebagi sebuah kemunduran. Banyak kalangan muda enggan untuk belajar budaya dan adat yang ada di tengah- tengah mereka. Menurut responden belajar budaya merupakan sebuah kemunduran jika dilakukan oleh anak-anak muda. Hal ini kemudian membuat beberapa kalangan menilai pesemis terhadap keberlangsungan budaya itu sendiri.

Terkait fenomena budaya global yang terus berkembang, sebanyak 37 responden atau $56,91 \%$ dari total menyatakan sangat setuju terkait terjadinya fenomena ini merupakan ancaman budaya lokal Kota Padangsidimpuan. Sebanyak 11 responden atau sebesar 16,91\% menyatakan setuju jika saat ini budaya lokal mulai mengancam eksistensi budaya lokal. Hanya sebanyak 17\% atau sebesar 26,18\% dari total responden yang tidak menganggap budaya lokal sebagai ancaman terhadap budaya lokal Kota Padangsidimpuan.

Gempuran budaya global yang datang memang seakan sulit untuk dihalau. Jika Indonesia mengenal berbagai hasil akulturasi budaya. Saat ini masyarakat seakan tidak lagi memiliki daya semacam itu. Masyarakat perlahan-lahan akan meninggalkan budaya yang dianggap tidak dapat memenuhi tuntutan jaman menurut mereka. Akhirnya bukanya terjadi penyatuan budaya malah budaya lokal yang pada akhirnya akan tergerus dengan budaya baru. Perspektif masyarakat yang menganggap budaya barat sebagai kiblat moderenisasi memperparah proses degradasi budaya lokal oleh budaya global.

Seluruh responden peduli terhadap perkembangan dan pentingnya budaya lokal untuk dipertahankan. Sebanyak 65 responden atau 100\% menyatakan jika budaya lokal Kota Padangsidimpuan harus dipertahankan. Pandangan responden diatas merupakan bentuk optimisme bahwa budaya masih dapat mengakomodir kebutuhan hidup masyarakat saat ini. Hal ini senada seperti yang diuangkapkan oleh Bapak Hite: “...kalau saya priibadi saya menjawab sangat layak dipertahankan. Kita boleh saja mengikuti perkembangan. Tapi kita juga harus menoleh kebelakang. Selama ini apakah budaya memiliki dampak negatif terhadap kita. Jika tidak ya harus kita pertahankan..."

Pada zaman saat ini Modernisasi menunjukkan suatu perkembangan dari struktur sistemsosial, suatu bentuk peruba"an yang berkelanjutan pada aspek-aspek kehidupan. Modernisasi suatu kelompok satuan sosial atau masyarakat, menampilkan suatu pengertianyang berkenaan dengan bentuk upaya untuk menciptakan kehidupan masyarakat yang sadar dan kondusif terhadap tuntutan dari tatanan kehidupan yang semakin mengglobal pada saat ini dan mendatang. Dengan kata lain, budaya harusnya tidak ditempatkan pada posisi yang berseberangan dengan moderenisasi.

Sebanyak 33 atau $50,72 \%$ dari total responden menyatakan jika saat ini budaya lokal tidak ada di dalam kurikulum pelajaran Kota Padangsidimpuan. Sementara itu sisanya sebanyak 32 atau 49,28\% dari total responden menyatakan sangat setuju jika saat ini budaya lokal masih ada di dalam kurikulum pelajaran di sekolah-sekolah Kota Padangsidimpuan. Di Kota Padang Sidimpuan ternyata ditemukan beberapa kasus bahwa tidak menjadi bagan dari kurikulum pembelajaran siswa di tingkatan SMP. Kebanyakan banyak sekolah di Kota Padang Sidimpuan tidak memberikan materi belajar muatan lokal kepada siswa. Hal ini terjadi karena siswa lebih di fokuskan untuk belajar tentang materi-materi yang akan diujikan pada ujuan nasional.

Menanggapi pentingnya peran budaya lokal dalam kurikulum pelajaran, sebanyak 32 atau sebesar 49,27\% dari total responden menyatakan sangat setuju. Semetara itu sebanyak 24 atau sebesar 36,91\% menyatakan setuju jika muatan budaya lokal memiliki peran penting. Dari 65 responden, hanyak 9 atau sebesar 13,82\% yang menyatakan tidak setuju jika muatan lokal dalam kurikulum memiliki 
peran penting dalam usaha mempertahankan budaya lokal di Kota Padangsidimpuan.

Dalam usaha mempertahankan eksistensi budaya lokal diharapkan semua pihak berperan, utamanya kepala sekolah. Dari data di atas, sebanyak 61 atau sebesar 93,96\% dari total responden menyatakan biasa saja menanggapi hal ini. Sebanyak 2 atau sebesar $3,02 \%$ responden menyatakan setuju jika pidato kepalas sekolah harus memuat pelestarian budaya lokal. Sisa responden sebanyak 2 atau sebesar 3,02\% dari total responden menyatakan tidak setuju jika pidato kepala sekolah harus memuat pesan pelestarian budaya lokal.

Tanggapan responden terkait pidato kepala Dinas di dalam upacara ataupun kegiatan-kegiatan lainnya. Sebanyak 15 atau sebesar 23,09\% responden menyatakan setuju jika selama ini pidato Kepala Dinas Pendidikan selalu memuat budaya lokal. Sebanyak 32 atau sebesar 49,28\% menyatakan biasa saja terkait hal ini. Sementara itu sebanyak 18 atau sebesat $27,63 \%$ menyatakan tidak setuju dengan pertanyaan adanya budaya lokal yang disinggung dalam pidato Kepala Dinas Pendidikan.

Usaha pelestarian budaya lokal tentunya dapat ditanamkan sejak dini dimulai dari bangku sekolah. Sebanyak 30 atau sebesar $46,18 \%$ dari total responden menyatakan sangat setuju jika budaya lokal diterapkan dalam aktivitas pembelajaran di sekolah. Sebanyak 24 atau sebesar 36,90\% responden menyatakan jika budaya lokal belum diterapkan dalam aktivitas pembelajaran di sekolah. Sebanyak 9 atau sebesar 13,80\% responden menyatakan sangat tidak setuju dan hanya sebanyak 2 atau sebesar 3,02\% responden yang menyatakan setuju jika saat ini budaya lokal sudah diterapkan dalam aktifitas pembelajaran di sekolah.

Pada saat ini sekolah di Kota Padangsidimpuan tidak menyediakan pelajara khusus yang memuat budaya lokal. Sebanyak 52 atau sebesar $80 \%$ total responden menyatakan tidak setuju jika saat ini sekolah telah menyediakan pelajaran khusus yang menuat budaya lokal. Sementara itu sisanya sebanyak 13 atau sebesar 20\% responden menyatakan sangat tidak setuju jika saat ini sekolah di Kota Padangsidimpuan telah menyediakan pelajaran khusus yang memuat budaya lokal.

Berdasarkan data yang didapat, sebanyak 54 atau sebesar 83,19\% responden menyatakan tidak setuju jika saat ini terdapat tema budaya lokal yang secara khusus telah diterapkan di sekolah. Sebanyak 9 atau sebesar 13,80\% menyatakan sangat tidak setuju, sementara itu hanya sebanyak 2 atau sebesar 3,02\% menyatakan sangat setuju jika saat ini tema budaya lokal telah diterapakan secara khusus di sekolah-sekolah di Kota Padangsidimpuan. Dengan data ini dapat disimpulkan bahwa budaya lokal tidak mendapat tempat kusus dalam kehidupan belajar mengajar di sekolah.

Dari data yang didapat sebanyak 28 atau sebesar 43,09\% responden menyatakan setuju jika tema budaya lokal diterapkan pada mata pelajaran PPKn. Sisanya, sebanyak 37 atau sebesar 56,91\% responden menyatakan biasa saja menanggapi hal ini. Tema budaya lokal sejatinya cocok dimasukkan ke dalam mata pelajaran seni dan budaya guna menjaga kelestariannya. Berdasarkan data yang di dapat, sebanyak 28 atau sebesar 43,09\% menyatakan sangat setuju menanggapi hal ini. Sebanyak 28 atau sebesar 43,09\% menyatakan setuju dengan dimasukkannya budaya lokal di mata pelajaran seni dan budaya. Hanya sebanyak 9 atau sebesar 13,82\% yang menyatakan tidak setuju jika budaya lokal diterapkan di mata pelajaran seni dan budaya.

Dari data yang didapat, jika sebanyak 28 atau sebesar 43,09\% responden menyatakan sangat setuju jika saat ini tema budaya lokal telah diterapkan pada mata pelaharan seni dan kerajinan tangan. Sebanyak 28 atau sebesar $43,09 \%$ responden menyatakan setuju jika saat ini tema budaya lokal telah diterapkan pada mata pelajaran seni dan kerajinan tangan. Hanya sebanyak 9 atau sebesar13,82\% responden yang menyatakan tidak setuju jika saat ini tema budaya lokal telah diterapkan pada mata pelajaran seni dan kerajinan tangan.

Terkait adanya pelajaran tentang bahasa daerah di sekolah, sebanyak 15 atau sebesar 
23,09\% menyatakan biasa saja. Sebanyak 17 atau sebesar 26,18\% menyatakan tidak setuju jika saat ini bahasa daerah telah diajarkan di sekolah di Kota Padangsidimpuan. Sementara itu sebanyak 33 atau sebesar 50,73\% responden menyatakan sangat tidak setuju terkait pernyataan saat ini bahasa daerah masuk dalam bahan pelajaran di sekolah.

Dari data yang didapat, dapat dilihat sebanyak 45 atau sebesar69,28\% total responden menyatakan sangat setuju jika keterbatasan pemahaman budaya lokal menjadi kendala dalam proses pengajaran di sekolah. Sebanyak 18 atau sebesar 27,70\% menyataka setuju, sementara itu hanya 2 atau sebesar $3,02 \%$ yang menyatakan tidak setuju jika keterbatasan pemahaman budaya lokal menjadi kendalam dalam proses pengjaran di sekolah di Kota Padangsidimpuan.

Literasi dalam proses belajar-mengajar merupakan hal yang penting, berdasarkan data di atas, dapat dilihat sebanyak 37 atau sebesar56,91\% menyatakan setuju jika minimnya literasi menjadi kendala dalam penerapan buday lokal di sekolah. Sebanyak 11 atau sebesar 16,91\% menyatakan sangat setuju dan sebanyak 17 atau sebesar 26,15\% menyatakan biasa saja terkait literasi yang menjadi kendala dalam penerapan budaya lokal di sekolah-sekolah di Kota Padang Sidimpuan.

Dari data yang diperoleh, sebanyak 22 atau sebesar 33,82\% responden menyatakan sangat setuju jika anggaran pendidikan merupakan hal penting dalam usaha penerapan budaya lokal. Sebanyak 24 atau sebesar 36,90\% menyatakan setuju dan sebanyak 19 atau sebesar 29,28\% responden menyatakan biasa saja terkati pentingnya anggaran pendidikan dalam usaha penerapan budaya lokal.

Dalam hal dukungan pemerintah daerah dalam mendukung penerapan budaya lokal di sekolah, sebanyak 28 atau sebesar 43,09\% menyatakan setuju jika saat ini pemerintah telah memberikan kebijakan yang mendukung. Sebanyak 9 attau sebesar 19,82\% menyatakan senagat setuju. Sementara itu sebanyak 13 atau sebesar 20\% responden menyatakan biasa saja, dan sebanyak 15 atau sebesar 23,09\% menyatakan tidak setuju jika saat ini pemerintah daerah Kota Padangsidimpuan telah mengeluarkan kebijakan yang mendukung penerapan budaya lokal di Sekolah.

Terkait adanya budaya lokal yang ditampilkan dalam pertunjukan sekolah, sebanyak 28 atau sebesar 43,09\% responden menyatakan setuju, sebanyak 9 atau sebesar13,82\% responden menyatakan sangat setuju jika saat ini budaya lokal ditampilkan dalam pertunjukan sekolah. Sebanyak 13 atau sebesar 20\% menyatakan biasa saja, dan sebanyak 15 atau sebesar 23,09\% menyatakan tidak setuju jika saat ini sekolah sering mengadakan pertunjukan tentang budaya lokal Kota Padangsidimpuan.

Dari data yang didapat, sebanyak 43 atau sebesar 66,18\% responden menyatakan setuju dan sebanyak 4 responden menyatakan sangat setuju jika dalian na tolu dikenalkan di sekolah. Sementara itum sebanyak 9 responden menyatakan tidak setuju dan 9 lainnya sangat tidak setuju terkait pernnyataan dalian na tolu telah dikenalkan di sekolah di Kota Padangsidimpuan.

Tarombo merupakan budaya lokal Kota Padangsidimpuan, berdasarkan data di atas dapat dilihat sebanyak 28 atau sebesar 43,09\% responden menyatakan sangat setuju tarombo telah dikenalkan di sekolah. Sebanyak 15 sebesar 23,09\% menyatakan tidak setuju, sebanyak 20 responden menyatakan sangat tidak setuju jika saat ini tarombo telah dikenalkan di sekolah di Kota Padangsidimpuan. Hanya sebanyak 2 atau sebesar3,02\% yang menyatakan setuju jika saat ini tarombo sudah dikenalkan di sekolah di Kota Padangsidimpuan.

Dari data yang didapat, bahwa bahasa Mandailing dan Angkola tidak dipelajari di sekolah-sekolah Kota Padangsidimpuan. Sebanyak 39 atau sebesar 60\% responden menyatakan tidak setuju, sementara itu sisanya sebanyak 26 responden menyatakan sangat tidak setuju terhadap pernyataan adanya pelajaran tentang bahasa Mandailing dan Angkola di sekolah. Berdasarkan data yang didapat, seluruh responden dengan jumlah 65 orang menyatakan tidak ada pelajaran terkait 
aksara Mandailing dan Angkola di sekolahsekolah di Kota Padangsidimpuan.

Dari data yang didapat, sebanyak 43 atau sebesar $66,18 \%$ responden menyatakan tidak setuju terkait adanya pelajaran tentang tor-tor Mandailing dan Angkola diajarkan di sekolah. Sebanyak 9 atau sebesar 13,84\% responden menyatakan setuju jika saat ini tor-tor Mandailing dan Angkola telah diajarkan di sekolah, sebanyak 9 responden lainnya menyatakan sikap biasa saja terkait pernyataan ini. Sisanya, sebanyak masing-masing 2 responden atau sebesar 3,02\% menyatakan sangat setuju dan sangat tidak setuju terkait adanya materi pelajarang tor-tor Mandailing dan Angkola yang telah diajarkan di sekolah.

Selama ini adat Gondang Sambilan tidak masuk dalam pelajaran di sekolah. Sebanyak 48 atau sebesar $73,82 \%$ responden menyatakan tidak setuju, sisanya sebanyak 17 atau sebesar $26,18 \%$ responden menyatakan sangat tidak setuju terkait pertnyataan gondang sambilan tela diajarkan di sekolah di Kota Padangsidimpuan.

Upacara markobar/marhobar merupakan salah satu budaya Lokal Kota Padangsidimpuan. Akan tetapi berdasarkan data di atas, dapat dilihat tidak ada pengajaran tentang upacara markobar di sekolah-sekolah di Kota Padangsidimpuan. Sebanyak 11 atau sebesar 16,92 menyatakan tidak setuju dengan pernyataan bahwa upacara markobar telah diajarkan di sekolah. Sementara itu sebanyakk 54 atau $83,07 \%$ menyatakan sangat tidak setuju dengan pernyataan ini.

Berdasarkan data yang didapat, responden menyatakan tidak adanya pelajaran yang memberikan materi tentang cerita rakyat setempat. Hal ini dapat dilihat dari jawaban responden sebanyak 43 atau sebesar $66,18 \%$ yang menyatakan tidak setuju dan sisanya sebanyak 22 atau sebesar 33,82\% responden menyatakan sangat tidak setuju terkait pernyataan adanya materi pelajaran yang mengajarkan tentang cerita rakyat setempat.

Kota Padangsidimpuan memiliki seni budaya lokal yang berbentuk permainan, akan tetapi berdasarkan data di atas sebanyak 30 atau sebesar $46,18 \%$ responden menyatakan tidak setuju terkait adanya pengajaran seni permainan lokal di sekolah. Sebanyak 15 atau sebesar 23,09\% menyatakan sangat tidak setuju. Hanya sebanyak 2 atau sebesar 3,02\% yang menyatakan sangat setuju. Sisanya sebanyak masing-masing 9 atau sebesar $13,82 \%$ responden menyatakan setuju dan biasa saja terkait pernyataan adanya pengajaran seni permainan lokal setempat di sekolah-sekolah Kota Padangsidimpuan.

Budaya Kota Padangsidimpuan memilki sinondang dan mantra-mantara yang terkait dengan pertanian. Sebanyak 28 atau sebesar 43,09\% responden menyatakan sangat tidak setuju terkait pernyataan adanya pengajaran tentang sinondang di sekolah. Sebanyak 22 atau sebesar33,82\% responden menyatakan tidak setuju, dan sisanya sebanyak 15 atau sebesar $23,09 \%$ responden menyatakan biasa saja terkait pernyataan adanya pengajaran sinondang di sekolah selama ini.

Dari data yang didapat, sebanyak 48 atau sebesar $73,8 \%$ responden menyatakan jika seragam sekolah siswa tidak mengandung unsur budaya lokal. Sebanyak 15 atau sebesar $23,1 \%$ menyatakan setuju dan hanya 2 atau sebesar 3,1\% yang menyatakan sangat setuju.

Berdasarkan data yang didapat, sebanyak 28 atau sebesar 43,09\% menyatakan sangat setuju denga pernyataan adanya petuah lokal yang terpampang di sekolah. Sisanya sebanyak 37 atau sebesar $56,91 \%$ responden menyatakan tidak setuju terkait pernyataan jika di sekolah mereke terpampang petuah-petuah lokal.

Terkait adanya ornamen sekolah yang mengandung unsur budaya lokal, sebanyak 50 atau sebesar 76,9 responden menyatakan tidak setuju dengan pernyataan ini. Sementara itu sebanyak 15 atau sebesar 23,07\% responden menyatakan adanya ornamen yang mengandung unsur budaya lokal di sekolah mereka.

Berdasarkan data yang didapat dapat dilihat sebanyak 50 atau sebesar 76,91\% responden menyataka sangat setuju terkait adanya upaya pemerintah Kota Padangsidimpuan dalam melakukan upaya pengembangan budaya lokal. Sementara itu 
sebanyak 15 aatau sebesar 23,09\% lainnya menyatakan setuju dengan pernyataan ini.

Berdasarkan data yang didapat, sebanyak 28 atau sebesar 43,09\% responden menyatakan sangat tidak setuju dengan pernyataan adanya beasiswa yang diberikan pemerintah Kota Padangsidimpuan kepada siswa lokal yang mengenyam pendidikan budaya di Universitas. Sebanyak 22 atau sebesar 33,82\% menyatakan tidak setuju dan sebanyak 15 atau sebesar 23,09\% menyatakan biasa saja. Dapat disimpulkan bahwa pemerintah Kota Padangsidimpuan belum memberikan beasiswa kepada siswa lokal yang mengenyam pendidikan budaya di universitas.

Dari data yang didapat, sebanyak 37 atau sebesar 56,91\% responden menyatakan tidak setuju telah adanya pelatihan yang diberikan kepada guru sebagai pengembanagan budaya lokal. Sementara itu sebanyak 28 atau sebesar 43,09\% menyatakan sikap biasa saja terkait pernyataan ini.

Sebanyak 52 atau sebesar $80 \%$ responden menyatakan sangat setuju bahwa selama ini pemerintah Kota Padangsidimpuan pernah mengadakan festival budaya lokal. Sebanyak 11 atau sebesar 16,9\% responden menyatakan setuju, hanya 2 rseponden yang menyatakan tidak setuju terkait pernahnya pemerintah Kota Padangsidimpuan melakukan festival ataupun pameran yang bertemakan budaya lokal.

Dari data yang didapat, disimpulkan bahwa pemerintah Kota Padangsidimpuan memberikan perhatian terhadap sanggarsanggar budaya lokal. Sebanyak 28 atau sebesar $43,09 \%$ responden menyatakan sangat setuju, sebanyak 33 atau sebesar 50,7\% menyatakan setuju. Hanya 4 responden atau sebesar 6,6\% yang menyatakan biasa saja terkait pernyataan ini.

Dari tabel yang didapat, sebanyak 50 atau sebesar 76,91\% responden tidak mengetahui adanya anggaran yang diberikan pemerintah kota kepada penggiat budaya lokal. Sementara itu sebanyak 15 atau sebesar 23,09\% responden menyatakn setuju terkait pernyataan jika selama ini pemerintah Kota
Padangsidimpuan telah memberikan anggaran kepada penggiat budaya lokal.

Berdasarkan data yang didapat, sebanyak 24 atau sebesar $36,91 \%$ responden menyatakan setuju terkait pernyataan adanya perhatian yang diberikan DPRD terhadap pengembangan budaya lokal. Sementara itu sebanyak 41 atau sebesar 63,09\% menyatakan biasa saja atau tidak mengetahui adanya perhatian yang diberikan DPRD terhadap pengembangan budaya lokal.

\section{SIMPULAN}

Budaya lokal masyarakat Kota Padang Sidimpuan telah menjadi bagian yang tidak terpisahkan dalam kehidupan masyarakat. Hal ini dapat dilihat dari berbagai aktivitas masyarakat seperti dalam ritual adat kemasatrakatan maupun sistemkekerabatan. Di Kota Padang Sidimpuan sekolah tingkat SMP ternyata tidak memberikan ruang khusus terhadap budaya lokal untuk tumbuh dan berkembang. Pemerintah daerah seperti Dewan Perwakilan Rakyat Daerah (DPRD) Kota Padang Sidimpuan maupun Pemerintah Kota Padang Sidimpuan dinilai belum dapat memberikan sumbangsihnya terhadap keberlangsungan budaya lokal di daerah.

\section{DAFTAR PUSTAKA}

Alwasilah, A.C., dkk.. (2009). Etnopedagogi Landasan Praktek Pendidikan dan Pendidikan Guru. Bandung: Kiblat.

Bagus, L. (2000). Kamus Filsafat. Jakarta: PT Gramedia Pustaka Utama.

Borgatta, E.F. dan Marie L.B. (1992). Encyclopedia of Sociology. New York : Macmillan Publishing Company.

Brannen, J. (1997). Memadu Metode Penelitian Kualitatif dan Kuantitatif. (Terjemahan Kurde dkk.). Samarinda: Fakultas TarbiyahIAIN Samarinda.

Dhofier, Z. (1982). Tradisi Pesantren: Studi Tentang Pandangan Hidup Kyai. Jakarta: LP3S.

Fudyartanta, K. (1995). Acuan Wawasan Pendidikan Budi Pekerti: Yogyakarta: Majelis Luhur Persatuan Taman Siswa

Garna, J.K., (1997). Pemikiran Modern dan Ilmu Pengetahuan Sosial. Bandung: Primaco Akademica CV. 
Armansyah Matondang, Yurial Arif Lubis; Agung Suharyanto, Eksistensi Budaya Lokal Dalam Usaha

Gunawan, A.H. (2000). Sosiologi Pendidikan: Suatu Analisis Sosiologi Tentang Pelbagai Problem Pendidikan, Jakarta: Rineka Cipta.

Hofsteede, W. (1994). Pembangunan Masyarakat: Society in Transition

. Yogyakarta: Gajah Mada University Press.

Jarolimek, J. (1990). Social Studies in Elementary Education. New York: Macmillan Publishing Company. Kartasapoetra dan Hartini. (1992).

Muhadjir, N. (2000). Metodologi Penelitian Kualitatif. Yogyakarta: Rake Sarasin.Parsons, Talcot. (1995). Sistem Sosial: Kerangka Konseptual untuk Menganalisis Struktur Masyarakat. (Terjemahan Somardi dan Editor Akhli Sudardja Adiwikarta). Jawa Barat :Ikatan Sosiologi Indonesia.

Ritzer, G. (1992). Sociology: A Multiple Paradigm Science. (disadur oleh Alimandan). Jakarta: CV Rajawali.

Putra, H.S.A. (1988). Minawang: Hubungan PatronKlien di Sulawesi Selatan. Yogyakarta: 